Abbreviated Key Title: Sch J Econ Bus Manag

ISSN 2348-8875 (Print) | ISSN 2348-5302 (Online)

Journal homepage: https://saspublishers.com/sjebm/

\title{
Social Network and Family Entrepreneurship Choice -Empirical Evidence from CHFS
}

\author{
Wang Jingxue*
}

School of Finance Guangdong University of Foreign Studies Guangzhou 510000, China

DOI: $10.36347 /$ sjebm.2020.v07i08.005

| Received: 09.08.2020 | Accepted: 17.08.2020 | Published: 19.08.2020

*Corresponding author: Wang Jingxue

Abstract

Review Article

This essay uses the 2011, 2013 and 2015 China Household Finance Survey data to empirically analyze the impact of social networks on household entrepreneurship and its mechanism. After correcting the endogenous problem, this article finds that social networks can help increase the probability of urban and rural families starting business Social networks can increase information acquisition, reduce information asymmetry, and reduce transaction costs, thereby helping families accurately understand and grasp market dynamics, and have a positive impact on the possibility of family entrepreneurship. At the same time, social networks have significantly increased the possibility of family entrepreneurship by broadening financing channels and easing credit constraints.

Keywords: Social network, Family entrepreneurship, financing channels, Information acquisition.

Copyright @ 2020: This is an open-access article distributed under the terms of the Creative Commons Attribution license which permits unrestricted use, distribution, and reproduction in any medium for non-commercial use (NonCommercial, or CC-BY-NC) provided the original author and source are credited.

\section{INTRODUCTION}

In the 30 years since reform and opening up, China's GDP has grown rapidly. China's GDP has grown from 367.9 billion yuan in 1978 to 90309 trillion yuan in 2018. The economic boom in the past 30 years is inseparable from the support of private enterprises created by entrepreneurship. During the important period of China's economic new normal, developing private enterprises, stimulating people's entrepreneurial willingness, and releasing entrepreneurial potential is of vital significance to China's economic transformation.

China's economy is entering a new normal, and China's unemployment rate has risen slightly at this time. This is a big challenge for China in a state of economic transition. Entrepreneurship is a powerful way to slow down the unemployment rate. According to data from the National Bureau of Statistics of China, in 1978 there were 95.14 million urban employees in China, while the individual economy was only 150,000 , accounting for $0.16 \%$. In 2017 , there were 424.62 million urban employees, of which private enterprises and individual businesses accounted for $53.4 \%$, all private enterprises accounted for nearly $80 \%$, and the increase accounted for more than $100 \%$.Studies have shown that entrepreneurship can not only alleviate the unemployment rate, but also affect economic growth in three ways: creating knowledge spillovers, increasing the number of enterprises, and promoting competition and enterprise diversification. In September 2014, Li
Keqiang proposed at the Summer Davos Forum to set off a new wave of "mass entrepreneurship" and "grassroot entrepreneurship" on 9.6 million square kilometers of land, forming a new trend of "innovation by all people" and "innovation by everyone". Since then, Premier Li Keqiang has frequently mentioned "double innovation" in the first World Internet Conference, the executive meeting of the State Council, and the 2015 "Government Work Report". In 2015, the State Council issued the "Opinions of the State Council on Several Policies and Measures for Vigorously Promoting Mass Entrepreneurship and Innovation", clearly stating that entrepreneurship and innovation is an innovation-driven development path of great significance, which is to stabilize growth, expand employment, and stimulate the wisdom and creativity of hundreds of millions of people. A major move to promote vertical social mobility, fairness and justice.Many provinces and cities have issued policies and measures to encourage entrepreneurship. With the strong support of the state, the 2019 China Private Economy Report shows that in 2017, individual industrial and commercial households increased to $65,793,700$, and private enterprises increased to $27,262,800$. In 2017, the number of corporate legal entities nationwide was 18.0977 million, and private holding companies accounted for $97.0 \%$. Entrepreneurship The proportion of college students starting their own businesses in my country is also constantly increasing. According to data from the McCaus Institute, the entrepreneurial rate of college 
students in my country was only $2.9 \%$ in 2014 , while this figure increased to $4.78 \%$ in 2018 ; The source of funding for entrepreneurship of college students mainly relies on investment or borrowing from parents, relatives and friends, and personal savings, while the proportions of government funding and commercial venture capital are relatively small, indicating that the source of current college students' entrepreneurial funding mainly relies on social networks. The role of social networks in family entrepreneurship is selfevident, and many scholars have also empirically proved that social networks have a positive impact on family entrepreneurship through mechanisms such as information acquisition and entrepreneurial financing [1- 4],

This essay uses the 2011, 2013, and 2015 panel data of the China Household Finance Survey (CHFS) to study the impact of household social networks on household entrepreneurial choices. The results show that social networks have a significant positive impact on family entrepreneurship choices; the influence of social network on the possibility of rural family entrepreneurship choice is more important; social networks will also influence family entrepreneurial choices through the mechanisms of information acquisition and financing channels. This article will enrich the literature on the impact of social networks on family entrepreneurship.

\section{LITERATURE REVIEW}

\section{Literature review of entrepreneurship}

Family entrepreneurship is affected by many factors, which are mainly divided into two categories : one is the social environment, including institutional environment, infrastructure, government control, financial availability, economic conditions, etc. [5]; the other is Personal and family characteristics, such as personal risk appetite, education level, family social network, family initial wealth level and other factors [6, 7].

\section{The impact of social environmental factors on entrepreneurship}

Fairlie [8] analyzed data from the Current Population Survey (CPS) from 1996 to 2009 and found that during a recession, more people will start their own businesses; compared to those who have workers with lower salaries, the unemployed are more likely to start their own businesses. Duan and Du [5] used principal component analysis, factor analysis and probit model to analyze the data of college students in 7 cities including Beijing, Wuhan, Guangzhou, Nanjing, Tianjin, Xi'an and Shanghai, and found that the better the entrepreneurial environment, the willingness of college students to start a business Higher. Chen [9] based on the panel data of the China Comprehensive Social Survey (CGSS) 2006, 2008, 2010 and 2011, and regressed government regulation on the probability of individual entrepreneurship and found that the impact of government regulation on entrepreneurship was significantly negative, but government regulation mainly reduced The entrepreneurial probability of "selfemployment" does not significantly reduce the entrepreneurial probability of "boss". Zhang and Meng [10] made a horizontal and vertical comparison between China's entrepreneurial system environment and innovation driven economies from 2012 to 2016, and found that the lack of innovation and entrepreneurship activities in China is due to the imperfect laws and regulations, the unsound government guarantee mechanism and the weak application of new technologies. Chen et al. [5] used the probit model to test the impact of infrastructure on farmers' entrepreneurship based on the 2011, 2013 and 2015 data of the China Health and Senior Care Survey (CHARLS). The study found that transportation, communication and public health infrastructure are all significantly positively correlated with farmers' entrepreneurship, and communication infrastructure has the greatest positive impact on farmers' entrepreneurship. A series of studies have proved that the macro entrepreneurial environment is an important factor influencing family entrepreneurial choices.

\section{The influence of personal and family characteristics on entrepreneurship}

Chen et al. [5] showed that household wealth and farmers' entrepreneurship are significantly positively correlated, which indicates that farmers' entrepreneurial activities face liquidity constraints [5]. Similarly, based on the chfs data of 2011 and 2013, Yang and Zhang [7] found that the savings rate significantly reduced the entrepreneurial intention of households. After adding the control variable of family wealth, they found that family wealth had a significant positive impact on family entrepreneurship, but the effect of savings rate on family Entrepreneurship was no longer significant. Based on the 1992-1993 Wisconsin State Entrepreneur Data (WECS), Allen [11] found that women are less involved in family entrepreneurship. Chen [9] found that men have a higher probability of starting a business than women; age and the probability of starting a business show a significant inverted U-shaped relationship, and individuals with urban household registration have a lower probability of starting a business. Yin et al. [12] studied the impact of financial knowledge on family entrepreneurship based on the 2013 CHFS data. The study found that families with higher financial knowledge are more likely to start a business. Through further analysis, they found that financial literacy can increase the willingness of households to start a business through channels such as changing borrowing channel preferences, reducing credit constraints, increasing human capital, and reducing risk aversion. Cai et al. [9] analyzed the impact of housing price expectation on family Entrepreneurship Based on 2011 chfs data, and found that the expected rise in house price significantly increased the probability of home 
ownership family entrepreneurship. The expected house price increased the probability of home ownership family entrepreneurship through wealth effect. However, housing price expectation reduces the probability of starting a business by crowding out effect and substitution effect. Based on the data of chfs in 2015, Qin et al. [5] analyzed the impact of provincial foreign worker experience on family entrepreneurship. The study found that the foreign worker experience of the province significantly increased the possibility of family entrepreneurship through the accumulation of wealth and the improvement of human capital.

\section{Social network and family Entrepreneurship}

Some scholars have found that household networks will smooth household consumption, increase household borrowing, and increase household income. Based on the survey data of migrant workers in Beijing in 2009, ye et al. [17] found that the larger the social network, the higher the wages of migrant workers. Based on China's rural financial survey in 2009, Yi et al. [13] found that social network can smooth household consumption and reduce household savings rate significantly. The effect is greater in families with lower incomes. Kinnan and Townsend [14] found that social network can significantly promote household lending based on rural data in Thailand.

More and more scholars began to explore the impact of social network on family entrepreneurship. Allen [11] defines social networks as social connections that can maintain social status and obtain emotional support, material assistance, and service information through contact. After empirical analysis using the data of Wisconsin entrepreneurs in 1992-1993, Allen found that social networks have a positive effect on family entrepreneurship, and there are gender differences in this impact. When the gender of entrepreneurs is female, social networks have no significant impact on entrepreneurial willingness. Yueh [15] used the data of China National Bureau of statistics in 2000 and found that social network has a significant positive impact on family entrepreneurial intention. However, for families who regard entrepreneurship as a second occupation and women who have experienced unemployment, social network has no significant influence on family entrepreneurship. Based on CFPS data in 2014, Chai [1] measured the social network as the frequency of relatives' contact, the degree of neighborhood harmony, the proportion of entertainment expenditure and the proportion of dining out expenses. It is found that kinship network and social network have a positive impact on family entrepreneurship, while neighborhood network is not significant. Social network can affect family entrepreneurship by improving family credit constraints. He and Yan [2] obtained similar results using CHFS, and found that social network has a significant positive impact on household credit constraints. Using 2011 CHFS data analysis, Zhang [3] found that social network has a significant positive impact on family entrepreneurship income, and social network will promote the increase of urban and rural entrepreneurship income by widening the channels of family access to information, but there are differences between urban and rural areas in this impact. Lu et al. [16] found that social relations will not only increase the channels of information acquisition and reduce transaction costs, but also ease the constraints of capital, trust and information, thus solving the problems of information asymmetry and unfair resource allocation in the process of entrepreneurship, so as to increase the probability of family entrepreneurship. $\mathrm{Hu}$ and Wang [4] draw similar conclusions using the 2016 micro data of China labor force dynamic survey (CLDs). A series of studies have proved that social network helps to increase the possibility of family entrepreneurship, and social network will increase the possibility of family entrepreneurship by improving family credit channels and access to information mechanism.

All in all, social networks will significantly increase the possibility of family entrepreneurship by alleviating credit constraints and broadening access to information. Based on this, this article proposes the following assumptions:

Hypothesis 1, social network will increase the probability of family entrepreneurship

Hypothesis 2, social networks increase the possibility of family entrepreneurship by broadening financing channels and alleviating credit constraints

Hypothesis 3: Social network expands the probability of family entrepreneurship through information acquisition mechanism

Most of the previous literature only used crosssectional data for testing. In order to improve the stability of the empirical results, this essay uses multiyear data. This article enriches the literature in the field of social networks and family entrepreneurship.

\section{Variables and data}

This article uses data from the China Household Finance Survey (CHFS) conducted by Southwestern University of Finance and Economics in 2011, which covers 25 provinces across the country and is representative of Chinese households. After excluding families under the age of 18 and missing values, 6130 samples were finally left.

\section{Family entrepreneurship variables}

After referring to him and Yan [7], this article selects whether the family is engaged in industrial and commercial production and operation to measure family entrepreneurial activities to measure family entrepreneurial activities. According to the design of CHFS questionnaire related questions, this essay sets family entrepreneurial activities as dummy variables, when engaged in industry and commerce $=1$, others $=$ 0 . 


\section{Social network}

The main explanatory variable of this essay is social network. In reference to Zhang et al. [10] and he he [2], this essay selects the logarithm of the sum of cash or non-cash expenditures of families on Spring Festival and other holidays and weddings as the main proxy variable of social network. At the same time, in the process of robustness test, this essay also selects the logarithm of household communication expenditure as the proxy variable of social network to test the robustness of benchmark conclusion.

\section{Control variables}

Other control variables in this essay mainly include family characteristics and personal characteristics of the head of the household. By referring to Zhang et al. [3] and He et al. [2], this essay selects variables such as family size, number of family workers, age of head of household, gender, years of education, party membership, married status, selfowned housing status, risk aversion, risk preference and health status.

\section{Mechanism variable}

When testing the credit constraint mechanism, this essay refers to Zhang et al. [3] and chfs questionnaire, and selects the dummy variables of "whether the family self-supporting industry and commerce obtains bank loans" and "whether they are subject to credit constraints" to measure the availability of formal finance and credit constraints respectively. At the same time, this essay selects "whether there are loans from other channels except bank loans" and "whether there are loans from relatives and friends" as proxy variables of private financing. When investigating the information acquisition mechanism of social network, this essay selects "the cost of dining out last month" to measure the situation of family information acquisition.

The explained variable in this essay is whether family entrepreneurship is a virtual variable. Therefore, we choose probit model for analysis. The model is shown in the following formula:

$p\left(b u \sin e s s=1 \mid X_{i}\right)=F\left(a_{i}+\right.$ socia $\ln$ etwork $\left.+a_{k} Z_{k i}\right)$

Business indicates whether the family is engaged in industrial and commercial operation, social network refers to family social network, and $Z_{\mathrm{ik}}$ refers to a series of control variables such as family information and household head information.

Table-1: Statistical description

\begin{tabular}{|c|c|c|c|c|c|c|}
\hline Variable name & Variable definition & Obs & Mean & Sd & Min & Max \\
\hline business & & 6,130 & .1466558 & .3537913 & 0 & 1 \\
\hline Social Networks & The number of gifts for Spring Festival & 6,130 & 8 & 1.129136 & 3.401197 & 12.61154 \\
\hline Age & Age of head of household & 6,130 & 50.04405 & 13.65911 & 18 & 112 \\
\hline Male & $\begin{array}{l}\text { Dummy variable, when the head of household is } \\
\text { male, the value is } 1\end{array}$ & 6,130 & 0.7371941 & 0.4401938 & 0 & 1 \\
\hline Marriage & $\begin{array}{l}\text { Dummy variable, when the head of household is } \\
\text { married, the value is } 1\end{array}$ & 6,130 & 0.8954323 & 0.3060205 & 0 & 1 \\
\hline Party & $\begin{array}{l}\text { Dummy variable, when the head of household is a } \\
\text { member of the Communist Party, the value is } 1\end{array}$ & 6,130 & 0.1796085 & 0.3838923 & 0 & 1 \\
\hline Risk_aver & $\begin{array}{l}\text { Dummy variable, when the head of household is } \\
\text { to avoid risk, the value is } 1\end{array}$ & 6,130 & 0.5735726 & 0.4945978 & 0 & 1 \\
\hline Risk_pre & $\begin{array}{l}\text { When the head of household is the preference risk, } \\
\text { the value is } 1\end{array}$ & 6,130 & 0.1466558 & 0.3537913 & 0 & 1 \\
\hline Health & $\begin{array}{l}\text { Dummy variable, when the head of household is } \\
\text { healthy, the value is } 1\end{array}$ & 6,130 & 0.3838499 & 0.4863617 & 0 & 1 \\
\hline Edu_y & $\begin{array}{l}\text { The number of years of education for the head of } \\
\text { household is } 0,6 \text { for primary school, } 9 \text { for junior } \\
\text { high school, } 12 \text { for high school, } 15 \text { for junior } \\
\text { college, } 16 \text { for undergraduate, } 19 \text { for graduate, and } \\
22 \text { for doctor }\end{array}$ & 6,130 & 9.750897 & 4.066999 & 0 & 22 \\
\hline Rural & $\begin{array}{l}\text { When the household registration is in rural areas, } \\
\text { the value is } 1\end{array}$ & 6,130 & 0.4952692 & 0.5000184 & 0 & 1 \\
\hline Size & Total family size & 6,130 & 3.504568 & 1.48909 & 1 & 18 \\
\hline House & $\begin{array}{l}\text { Dummy variable, when the family owns a house, } \\
\text { the value is } 1\end{array}$ & 6,130 & 0.9177814 & 0.2747199 & 0 & 1 \\
\hline Num_work & Number of people with jobs at home & 6,130 & 1.89217 & 1.250989 & 0 & 9 \\
\hline Business_debt & $\begin{array}{l}\text { Dummy variable, when the family has industrial } \\
\text { and commercial loans, the value is } 1\end{array}$ & 6,130 & 0.0358891 & 0.1860287 & 0 & 1 \\
\hline Debt_other & $\begin{array}{l}\text { Dummy variable, when the family loans from } \\
\text { other channels, the value is } 1\end{array}$ & 6,130 & 0.1177814 & 0.3223754 & 0 & 1 \\
\hline Debt_f & $\begin{array}{l}\text { Dummy variable. When a family gets a loan from } \\
\text { a friend or family member, the value of the } \\
\text { variable is } 1\end{array}$ & 6,130 & 0.1070147 & 0.3091571 & 0 & 1 \\
\hline
\end{tabular}


Table 1 shows the descriptive statistics of the variables used in this article. After eliminating duplicate samples and outliers, 6,130 household samples were retained. It can be seen from the table that the average value of family entrepreneurship is 0.14 , which means that about $14 \%$ of families choose to start their own businesses. The logarithm average of gift money is 8 , and the average Chinese spends about 3,000 yuan in gift money for the Spring Festival a year. In addition, among the control variables, about $74 \%$ of household heads are men, and about $13 \%$ of household heads prefer risk. This shows that most households are risk averse. There is also a large age gap between household heads, with the youngest being 18 years old and the oldest being 112 years old. The average family size is 3 , and the number of people working at home is 1.8 , that is, more than half of the family members have jobs. There are very few people in the sample who have loans. Among them, households with formal loans account for about $13 \%$, and the ratios of households with loans from relatives and friends and other channels are about $10 \%$ and $12 \%$, respectively.

\section{EMPIRICAL ANALYSIS RESULTS \\ Basic empirical results}

Column (1) of Table 2 is the result of the probit regression of the social network on family entrepreneurship. Then we controlled the household characteristic variables and household head characteristic variables, and the results are shown in columns (2) and (3). With the addition of other control variables, social network has a significant positive effect on the probability of family entrepreneurship. A family with a wider social network has a greater probability of starting a business. This result is consistent with the analysis results of scholars such as $\mathrm{He}$ [2] and Lu [16], and Hypothesis 1 is confirmed.

Other control variables also have significant correlations with family entrepreneurship. Family size, risk appetite, health, education years, and rural families have a positive effect on family entrepreneurship. The age of the head of the household and risk aversion have a negative impact on family entrepreneurship. The larger the family size is, the more family members they have. They will have more social networks to obtain more entrepreneurial information and financing channels, which increases the possibility of family entrepreneurship. A family with a higher education level will have a broader network of classmates, which increases the family's probability of starting a business. Families who have their own houses will not be too nervous about funds and feel more secure, so they will choose to start a business boldly. Risk-conscious families believe that "the greater the risk, the greater the return", compared to risk-averse and risk-neutral families, it is easier to choose to start a business.

Table-2: Basic regression results

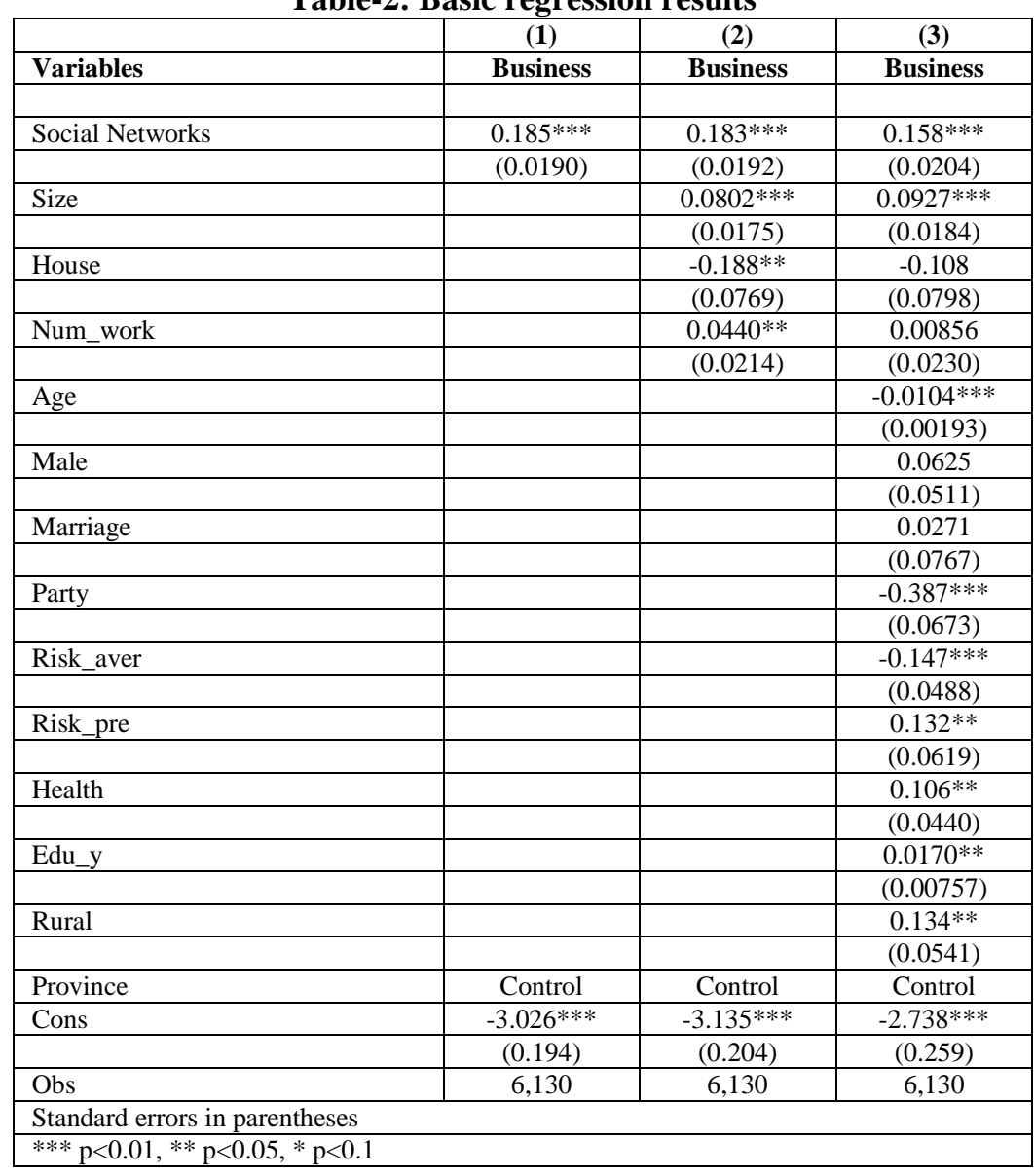


Wang Jingxue., Sch J Econ Bus Manag, August, 2020; 7(8): 249-260

\section{MECHANISM ANALYSIS RESULTS}

\section{Expand financing channels and credit constrain}

Referring to Wen [17], this essay uses the mediating effect to test whether the social network will expand the family financing channels. Columns (1) to (3) report the estimated results, which is the probit regression of social network to the formal channel industrial and commercial loans, other channels of loan financing, and relatives and friends lending behavior. Social network can not only increase the possibility of formal channels of industrial and commercial loans, but also increase the possibility of other channels of financing and the possibility of relatives and friends borrowing, which means that social network will promote family private financing. Social network can enhance the trust between relatives and friends. When trust increases, relatives and friends are not only willing to lend money to families, but also willing to help families get bank loans. Columns (4) to (6) of Table 3 show the empirical estimation results of the probability of family entrepreneurship by using commercial and industrial loans from formal channels, loans from other channels and loans from relatives and friends. The results show that bank loans, loans from other channels and loans from relatives and friends will significantly increase the probability of family entrepreneurship. All kinds of loans can help families get venture capital. According to the mediating effect test procedure of Wen [17], the above results show that social network can broaden the intermediary effect of family financing channels to increase the possibility of family entrepreneurship. Hypothesis 2 was initially confirmed.

Table-3: Results of expanding financing channels

\begin{tabular}{|c|c|c|c|c|c|c|}
\hline & (1) & (2) & (3) & (4) & (5) & (6) \\
\hline Variable & Debt_business & Debt_other & Debt_F & Business & Business & Business \\
\hline \multirow{2}{*}{ Social_network } & $0.131 * * *$ & $0.0662 * * *$ & $0.0639 * * *$ & $0.146^{* * * *}$ & $0.151 * * *$ & $0.151 * * *$ \\
\hline & $(0.0331)$ & $(0.0220)$ & $(0.0224)$ & $(0.0213)$ & $(0.0218)$ & $(0.0218)$ \\
\hline \multirow[t]{2}{*}{ Debt_business } & & & & $1.014 * * *$ & & \\
\hline & & & & $(0.0932)$ & & \\
\hline \multirow[t]{2}{*}{ Debt_other } & & & & & $1.071 * * *$ & \\
\hline & & & & & $(0.0603)$ & \\
\hline \multirow[t]{2}{*}{ Debt_F } & & & & & & $1.010 * * *$ \\
\hline & & & & & & $(0.0588)$ \\
\hline \multirow[t]{2}{*}{ Size } & 0.0455 & $0.0493 * *$ & $0.0612 * * *$ & $0.0935 * * *$ & $0.0807 * * *$ & $0.0813 * * *$ \\
\hline & $(0.0294)$ & $(0.0197)$ & $(0.0200)$ & $(0.0157)$ & $(0.0163)$ & $(0.0163)$ \\
\hline \multirow[t]{2}{*}{ House } & $0.308^{*}$ & -0.00674 & -0.0399 & $-0.129 *$ & -0.0959 & -0.102 \\
\hline & $(0.168)$ & $(0.0978)$ & $(0.0983)$ & $(0.0783)$ & $(0.0784)$ & $(0.0781)$ \\
\hline \multirow[t]{2}{*}{ Num_work } & 0.0369 & $0.0794 * * *$ & $0.0610 * *$ & $-0.00980 * * *$ & $-0.00923 * * *$ & $-0.00925 * * *$ \\
\hline & $(0.0370)$ & $(0.0252)$ & $(0.0256)$ & $(0.00190)$ & $(0.00194)$ & $(0.00194)$ \\
\hline \multirow[t]{2}{*}{ Age } & $-0.00894 * * *$ & $-0.00997 * * *$ & $-0.00995 * * *$ & 0.0499 & 0.0423 & 0.0478 \\
\hline & $(0.00322)$ & $(0.00218)$ & $(0.00222)$ & $(0.0503)$ & $(0.0515)$ & $(0.0515)$ \\
\hline \multirow[t]{2}{*}{ Male } & $0.168 *$ & 0.0867 & $0.115^{*}$ & 0.0360 & 0.0154 & 0.00680 \\
\hline & $(0.0912)$ & $(0.0587)$ & $(0.0603)$ & $(0.0764)$ & $(0.0775)$ & $(0.0773)$ \\
\hline \multirow[t]{2}{*}{ Marriage } & -0.0818 & 0.0905 & 0.0536 & $-0.426 * * *$ & $-0.398 * * *$ & $-0.389 * * *$ \\
\hline & $(0.125)$ & $(0.0884)$ & $(0.0894)$ & $(0.0690)$ & $(0.0704)$ & $(0.0702)$ \\
\hline \multirow[t]{2}{*}{ Party } & $0.207 * *$ & $-0.131 *$ & -0.0833 & $-0.134 * * *$ & $-0.136 * * *$ & $-0.129 * * *$ \\
\hline & $(0.0977)$ & $(0.0782)$ & $(0.0787)$ & $(0.0492)$ & $(0.0500)$ & $(0.0499)$ \\
\hline \multirow[t]{2}{*}{ Risk_aver } & $-0.204 * *$ & $-0.112 * *$ & -0.0880 & 0.0976 & 0.0841 & 0.0893 \\
\hline & $(0.0797)$ & $(0.0542)$ & $(0.0555)$ & $(0.0626)$ & $(0.0637)$ & $(0.0635)$ \\
\hline \multirow[t]{2}{*}{ Risk_pre } & $0.270 * * *$ & $0.191 * * *$ & $0.210 * * *$ & $0.111 * *$ & $0.135 * * *$ & $0.136 * * *$ \\
\hline & $(0.0904)$ & $(0.0693)$ & $(0.0706)$ & $(0.0439)$ & $(0.0448)$ & $(0.0447)$ \\
\hline \multirow[t]{2}{*}{ Health } & 0.0170 & $-0.105^{* *}$ & $-0.0971^{*}$ & $0.0181 * *$ & $0.0240 * * *$ & $0.0242 * * *$ \\
\hline & $(0.0706)$ & $(0.0496)$ & $(0.0507)$ & $(0.00714)$ & $(0.00734)$ & $(0.00734)$ \\
\hline \multirow[t]{2}{*}{ Edu_y } & 0.00311 & $-0.0242 * * *$ & $-0.0232 * * *$ & $0.110 * *$ & 0.0426 & 0.0354 \\
\hline & $(0.0122)$ & $(0.00800)$ & $(0.00816)$ & $(0.0548)$ & $(0.0562)$ & $(0.0563)$ \\
\hline \multirow[t]{2}{*}{ Rural } & $0.372 * * *$ & $0.533 * * *$ & $0.489 * * *$ & $0.0935 * * *$ & $0.0807 * * *$ & $0.0813 * * *$ \\
\hline & $(0.0943)$ & $(0.0628)$ & $(0.0639)$ & $(0.0157)$ & $(0.0163)$ & $(0.0163)$ \\
\hline Province & Control & Control & Control & Control & Control & Control \\
\hline \multirow[t]{2}{*}{ Cons } & $-4.115 * * *$ & $-2.332 * * *$ & $-2.295 * * *$ & $-2.650 * * *$ & $-2.826 * * *$ & $-2.822 * * *$ \\
\hline & $(0.521)$ & $(0.309)$ & $(0.311)$ & $(0.214)$ & $(0.219)$ & $(0.219)$ \\
\hline Obs & 6,040 & 5,984 & 5,984 & 6,130 & 6,130 & 6,130 \\
\hline \multicolumn{7}{|c|}{ Standard errors in parentheses } \\
\hline$* * * \mathrm{p}<0.01, * * \mathrm{p}$ & $5, * \mathrm{p}<0.1$ & & & & & \\
\hline
\end{tabular}


Wang Jingxue., Sch J Econ Bus Manag, August, 2020; 7(8): 249-260

This section constructs a cross term between gift money and credit constraints to verify whether social networks increase the probability of family entrepreneurship by easing credit constraints. With reference to Yin et al. [12], this essay defines "need but no application" or "application rejected" as being subject to credit constraints, and defines "need but no application" as demand-oriented credit constraint and "application rejected" as supply-oriented credit constraint. The results are shown in Table 4 . When the family has credit constraints, the larger the family social network, the more likely the family to choose entrepreneurship. The positive impact of social network on entrepreneurship is greater in families with credit constraints, which also reflects that social network can ease the credit constraints of families. Hypothesis 2 was confirmed.

Table-4: Analysis of credit constraints using cross items

\begin{tabular}{|c|c|c|c|}
\hline & (1) & (2) & (3) \\
\hline Variables & Business & Business & Business \\
\hline \multirow[t]{2}{*}{ Social_network } & $0.126 * * *$ & $0.127 * * *$ & $0.130 * * *$ \\
\hline & $(0.0236)$ & $(0.0236)$ & $(0.0236)$ \\
\hline \multirow[t]{2}{*}{ Credit_constrain } & $0.0203 * * *$ & & \\
\hline & $(0.00732)$ & & \\
\hline \multirow[t]{2}{*}{ Credit_constrain_sub } & & $0.0469 * * *$ & \\
\hline & & $(0.0137)$ & \\
\hline \multirow[t]{2}{*}{ Credit_constrain_dem } & & & 0.00362 \\
\hline & & & $(0.00809)$ \\
\hline \multirow[t]{2}{*}{ Size } & $0.0787 * * *$ & $0.0765 * * *$ & $0.0789 * * *$ \\
\hline & $(0.0208)$ & $(0.0208)$ & $(0.0208)$ \\
\hline \multirow[t]{2}{*}{ House } & -0.0522 & -0.0307 & -0.0446 \\
\hline & $(0.101)$ & $(0.102)$ & $(0.101)$ \\
\hline \multirow[t]{2}{*}{ Num_work } & -0.00230 & $-5.26 \mathrm{e}-05$ & $9.67 \mathrm{e}-06$ \\
\hline & $(0.0259)$ & $(0.0258)$ & $(0.0258)$ \\
\hline \multirow[t]{2}{*}{ Age } & $-0.00934 * * *$ & $-0.00953 * * *$ & $-0.00968 * * *$ \\
\hline & $(0.00223)$ & $(0.00222)$ & $(0.00222)$ \\
\hline \multirow[t]{2}{*}{ Marriage } & 0.0316 & 0.0353 & 0.0350 \\
\hline & $(0.102)$ & $(0.102)$ & $(0.102)$ \\
\hline \multirow[t]{2}{*}{ Party } & $-0.349 * * *$ & $-0.348 * * *$ & $-0.350 * * *$ \\
\hline & $(0.0737)$ & $(0.0738)$ & $(0.0736)$ \\
\hline \multirow[t]{2}{*}{ Risk_aver } & $-0.175 * * *$ & $-0.163 * * *$ & $-0.175 * * *$ \\
\hline & $(0.0564)$ & $(0.0565)$ & $(0.0564)$ \\
\hline \multirow[t]{2}{*}{ Risk_pre } & 0.101 & 0.100 & 0.102 \\
\hline & $(0.0703)$ & $(0.0704)$ & $(0.0702)$ \\
\hline \multirow[t]{2}{*}{ Health } & $0.101 * *$ & $0.0883^{*}$ & $0.0908^{*}$ \\
\hline & $(0.0506)$ & $(0.0504)$ & $(0.0505)$ \\
\hline \multirow[t]{2}{*}{ Edu_y } & $0.0205 * *$ & $0.0200 * *$ & $0.0201 * *$ \\
\hline & $(0.00892)$ & $(0.00891)$ & $(0.00892)$ \\
\hline \multirow[t]{2}{*}{ Rural } & $0.140^{* *}$ & $0.145^{* *}$ & $0.150^{* *}$ \\
\hline & $(0.0631)$ & $(0.0630)$ & $(0.0630)$ \\
\hline Province & Control & Control & Control \\
\hline \multirow[t]{2}{*}{ Cons } & $-2.480 * * *$ & $-2.478 * * *$ & $-2.487 * * *$ \\
\hline & $(0.312)$ & $(0.311)$ & $(0.311)$ \\
\hline Obs & 4,519 & 4,519 & 4,519 \\
\hline \multicolumn{4}{|c|}{ Standard errors in parentheses } \\
\hline \multicolumn{3}{|c|}{$* * * \mathrm{p}<0.01, * * \mathrm{p}<0.05, * \mathrm{p}<0.1$} & \\
\hline
\end{tabular}




\section{Increase access to information}

Zhang et al. [10] believe that China is a human society, and families can obtain a large amount of information at the dinner table. Therefore, families with larger social networks will increase their spending on dining out with friends and relatives in order to obtain information. This can reduce information asymmetry and transaction costs, thus increasing the probability of family entrepreneurship. Our results confirm this conjecture. In this essay, OLS model is used to regression the social network of dining out, and then probit regression of family entrepreneurship to dining out is conducted. The results are shown in Table 5. Social network significantly increased the expenditure of dining out, and dining out also significantly increased the possibility of family entrepreneurship. Therefore, it is confirmed that social network can increase the access to information to increase the possibility of family entrepreneurship. Hypothesis 3 is confirmed.

Table-5: Increase access to information

\begin{tabular}{|c|c|c|}
\hline & (1) & (2) \\
\hline Variables & Dining_out & business \\
\hline \multirow[t]{2}{*}{ Dining_out } & & $0.226 * * *$ \\
\hline & & $(0.0343)$ \\
\hline \multirow[t]{2}{*}{ Social_network } & $0.249 * * *$ & $0.132 * * *$ \\
\hline & $(0.0179)$ & $(0.0323)$ \\
\hline \multirow[t]{2}{*}{ Size } & $0.0453 * * *$ & $0.0789 * * *$ \\
\hline & $(0.0154)$ & $(0.0258)$ \\
\hline \multirow[t]{2}{*}{ House } & -0.00104 & -0.121 \\
\hline & $(0.0656)$ & $(0.113)$ \\
\hline \multirow[t]{2}{*}{ Num_work } & 0.0215 & -0.0164 \\
\hline & $(0.0220)$ & $(0.0359)$ \\
\hline \multirow[t]{2}{*}{ Age } & $-0.00770 * * *$ & $-0.00603 *$ \\
\hline & $(0.00173)$ & $(0.00320)$ \\
\hline \multirow[t]{2}{*}{ Male } & -0.0278 & 0.123 \\
\hline & $(0.0426)$ & $(0.0756)$ \\
\hline \multirow[t]{2}{*}{ Marriage } & $-0.118 *$ & 0.131 \\
\hline & $(0.0602)$ & $(0.109)$ \\
\hline \multirow[t]{2}{*}{ Party } & 0.0728 & $-0.386 * * *$ \\
\hline & $(0.0493)$ & $(0.0925)$ \\
\hline \multirow[t]{2}{*}{ Risk_aver } & -0.0150 & -0.0561 \\
\hline & $(0.0430)$ & $(0.0743)$ \\
\hline \multirow[t]{2}{*}{ Risk_pre } & $0.268 * * *$ & $0.224 * * *$ \\
\hline & $(0.0507)$ & $(0.0829)$ \\
\hline \multirow[t]{2}{*}{ Health } & 0.0200 & 0.0321 \\
\hline & $(0.0383)$ & $(0.0655)$ \\
\hline \multirow[t]{2}{*}{ Edu_y } & $0.0186^{* * *}$ & -0.00981 \\
\hline & $(0.00676)$ & $(0.0120)$ \\
\hline \multirow[t]{2}{*}{ Rural } & -0.0589 & $0.255^{* * *} *$ \\
\hline & $(0.0487)$ & $(0.0807)$ \\
\hline Province & -0.122 & -0.0300 \\
\hline \multirow[t]{2}{*}{ Cons } & $6.779 * * *$ & $-4.514 * * *$ \\
\hline & $(0.203)$ & $(0.442)$ \\
\hline Obs & 2,525 & 2,507 \\
\hline R-squared & 0.239 & \\
\hline \multicolumn{3}{|c|}{ Standard errors in parentheses } \\
\hline \multicolumn{3}{|c|}{$* * * \mathrm{p}<0.01, * * \mathrm{p}<0.05, * \mathrm{p}<0.1$} \\
\hline
\end{tabular}


Wang Jingxue., Sch J Econ Bus Manag, August, 2020; 7(8): 249-260

\section{ROBUSTNESS ANALYSIS}

We use the same definition of variables to test the data in 2013 and 2015, the results are shown in columns (1) (2) of table 7. The coefficient sign of social network is still significantly positive, which indicates that social network will increase the probability of family entrepreneurship. This confirms the robustness of our results. Then, referring to Zhang [3] and he [2], this essay uses communication expenditure to define family social network, and conducts probit regression on family entrepreneurship variables. The results are shown in column (3) of table 7 . The results show that social network still significantly increases the possibility of family entrepreneurship, so the results of this essay are robust.

Table-6: Result of Robustness analysis

\begin{tabular}{|c|c|c|c|}
\hline & (1) & $(2)$ & (3) \\
\hline & 2013 & 2015 & $\begin{array}{c}\text { Change variable } \\
\text { definition }\end{array}$ \\
\hline Variable & Business & Business & Business \\
\hline \multirow[t]{2}{*}{ Social_network } & $0.151 * * *$ & $0.142 * * *$ & \\
\hline & $(0.00979)$ & $(0.00872)$ & \\
\hline \multirow[t]{2}{*}{ LnCommunication_exp } & & & $0.330 * * *$ \\
\hline & & & $(0.0263)$ \\
\hline \multirow[t]{2}{*}{ Size } & $0.0483 * * *$ & $0.0512 * * *$ & $0.0656 * * *$ \\
\hline & $(0.00926)$ & $(0.00701)$ & $(0.0190)$ \\
\hline \multirow[t]{2}{*}{ House } & -0.00371 & -0.0449 & -0.123 \\
\hline & $(0.0240)$ & $(0.0366)$ & $(0.0815)$ \\
\hline \multirow[t]{2}{*}{ Num_work } & $0.0617 * * *$ & $0.163 * * *$ & 0.000579 \\
\hline & $(0.0120)$ & $(0.0100)$ & $(0.0234)$ \\
\hline \multirow[t]{2}{*}{ Age } & $-0.0182 * * *$ & $-0.0181 * * *$ & $-0.00629 * * *$ \\
\hline & $(0.00101)$ & $(0.000849)$ & $(0.00202)$ \\
\hline \multirow[t]{2}{*}{ Male } & 0.0120 & $0.0554 * *$ & 0.0819 \\
\hline & $(0.0274)$ & $(0.0236)$ & $(0.0519)$ \\
\hline \multirow[t]{2}{*}{ Marriage } & $0.0917 * *$ & 0.0204 & 0.0333 \\
\hline & $(0.0379)$ & $(0.0328)$ & $(0.0781)$ \\
\hline \multirow[t]{2}{*}{ Party } & $-0.292 * * *$ & $0.106 * * *$ & $-0.404 * * *$ \\
\hline & $(0.0339)$ & $(0.0236)$ & $(0.0686)$ \\
\hline \multirow[t]{2}{*}{ Risk_pre } & $-0.201 * * *$ & $-0.116 * * *$ & $-0.126 * *$ \\
\hline & $(0.0260)$ & $(0.0215)$ & $(0.0496)$ \\
\hline \multirow[t]{2}{*}{ Risk_aver } & $0.0589 *$ & $0.0838 * * *$ & $0.113 *$ \\
\hline & $(0.0356)$ & $(0.0321)$ & $(0.0629)$ \\
\hline \multirow[t]{2}{*}{ Health } & $0.152 * * *$ & $0.249 * * *$ & $0.112 * *$ \\
\hline & $(0.0229)$ & $(0.0311)$ & $(0.0449)$ \\
\hline \multirow[t]{2}{*}{ Edu_y } & $-0.00987 * * *$ & $-0.00955 * * *$ & 0.00664 \\
\hline & $(0.00368)$ & $(0.00311)$ & $(0.00774)$ \\
\hline \multirow[t]{2}{*}{ Rural } & -0.00451 & $-0.0685 * * *$ & $0.181 * * *$ \\
\hline & $(0.0258)$ & $(0.0230)$ & $(0.0549)$ \\
\hline Province & Control & Control & Control \\
\hline \multirow[t]{2}{*}{ Cons } & $-1.974 * * *$ & $-2.125 * * *$ & $-3.992 * * *$ \\
\hline & $(0.129)$ & $(0.125)$ & $(0.291)$ \\
\hline Obs & 21,696 & 28,032 & 5,957 \\
\hline \multicolumn{4}{|c|}{ Standard errors in parentheses } \\
\hline$* * * \mathrm{p}<0.01, * * \mathrm{p}<0.05, *$ & $<0.1$ & & \\
\hline
\end{tabular}

Liang [7] pointed out that because families are likely to consciously broaden the accumulated social capital in order to obtain entrepreneurial information. Therefore, the endogenous problem caused by reverse causality in the model in this essay will bias the estimation results. In order to solve the endogenous problem, this essay adopts the "average value of other family social networks in the community/village" as an instrumental variable. This essay uses the IV-Probit model to re-estimate the impact of social networks on family entrepreneurship. This is because relatives and neighbors in a Chinese community or village are related to the family social network, and the "average value of the social network of other families in the community/village" does not directly affect the entrepreneurial decision of the sample family. 
Wang Jingxue., Sch J Econ Bus Manag, August, 2020; 7(8): 249-260

Therefore, the "average value of the social network of other households in the community/village" satisfies the requirements of the exogeneity and relevance of instrumental variables. Table 7 shows the regression results of the average value of community/village social network to family entrepreneurship. From Table 7, it can be seen that the social network variables measured by the "average value of community/village social network" still have an effect on the probability of family entrepreneurship. The positive impact is basically consistent with the previous conclusions. However, the absolute value of the coefficient of the instrumental variable is greater than the coefficient of the basic regression. This may be due to the fact that the impact of the social network division of the community on family entrepreneurship is not homogeneous, and there is a Local Average Treatment Effect (LATE). Families with strong abilities and prefer to work freely are more inclined to choose home entrepreneurship and can get more benefits from entrepreneurship. Therefore, family entrepreneurship is more susceptible to the influence of community families. The regression coefficients estimated by the IV-probit model in this essay reflect the local average treatment effect, which is a weighted average, in which families with "strong ability and prefer to work freely" will have a greater weight, rather than the average based on the sample Treatment effect (ATE), so the coefficient of instrumental variable estimation has increased compared with the coefficient of benchmark regression.

Column 2 also shows the regression results of the first stage. It can be seen that the "average value of the community/village social network" has a significant positive correlation with the social network. The higher the "community/village social network average" of the family, the larger the family's social network. It proves that the instrumental variables in this article are not weak instrumental variables.

Table-7: The result of IV-Probit

\begin{tabular}{|c|c|c|}
\hline & (1) & (2) \\
\hline Variable & Business & Social_network \\
\hline \multirow[t]{2}{*}{ Average value of community / village social network } & $0.223 * * *$ & $0.885 * * *$ \\
\hline & $(0.0569)$ & $(0.0317)$ \\
\hline \multirow[t]{2}{*}{ Size } & $0.0898 * * *$ & $0.0516^{* * *}$ \\
\hline & $(0.0186)$ & $(0.0115)$ \\
\hline \multirow[t]{2}{*}{ House } & -0.122 & $0.240 * * *$ \\
\hline & $(0.0806)$ & $(0.0474)$ \\
\hline \multirow[t]{2}{*}{ Num_work } & 0.00513 & $0.0515 * * *$ \\
\hline & $(0.0231)$ & $(0.0144)$ \\
\hline \multirow[t]{2}{*}{ Age } & $-0.0100 * * *$ & $-0.00306 * * *$ \\
\hline & $(0.00196)$ & $(0.00111)$ \\
\hline \multirow[t]{2}{*}{ Male } & 0.0670 & -0.0322 \\
\hline & $(0.0511)$ & $(0.0302)$ \\
\hline \multirow[t]{2}{*}{ Marriage } & 0.0145 & $0.212 * * *$ \\
\hline & $(0.0773)$ & $(0.0435)$ \\
\hline \multirow[t]{2}{*}{ Party } & $-0.395 * * *$ & $0.131 * * *$ \\
\hline & $(0.0675)$ & $(0.0364)$ \\
\hline \multirow[t]{2}{*}{ Risk_aver } & $-0.140 * * *$ & $-0.0811 * * *$ \\
\hline & $(0.0490)$ & $(0.0301)$ \\
\hline \multirow[t]{2}{*}{ Risk_pre } & $0.122 * *$ & $0.116 * * *$ \\
\hline & $(0.0624)$ & $(0.0407)$ \\
\hline \multirow[t]{2}{*}{ Health } & $0.0994 * *$ & $0.0868 * * *$ \\
\hline & $(0.0443)$ & $(0.0269)$ \\
\hline \multirow[t]{2}{*}{ Edu_y } & 0.0133 & $0.0364 * * *$ \\
\hline & $(0.00815)$ & $(0.00429)$ \\
\hline \multirow[t]{2}{*}{ Rural } & $0.144 * * *$ & -0.0270 \\
\hline & $(0.0546)$ & $(0.0340)$ \\
\hline \multirow[t]{2}{*}{ Cons } & $-3.187 * * *$ & -0.0395 \\
\hline & $(0.444)$ & $(0.275)$ \\
\hline Obs & 6,130 & 6,130 \\
\hline \multicolumn{3}{|l|}{ Standard errors in parentheses } \\
\hline$* * * \mathrm{p}<0.01, * * \mathrm{p}<0.05, * \mathrm{p}<0.1$ & & \\
\hline
\end{tabular}




\section{Heterogeneity regression}

In view of the fact that many literatures regressed rural samples separately, we divided the samples into rural and urban to detect the urban-rural heterogeneity of the impact of social networks on family entrepreneurship. The results are shown in Table 8 . From Table 8 we can see that social networks can increase the probability of family entrepreneurship in both rural and urban areas. Compared with urban families, social networks have a greater positive impact on rural families' entrepreneurship. The reason may be that most of the families of the same clan live in the same village. Compared with the city, the social network is closer and mutual communication is more frequent. At the same time, financial availability in rural areas is lower than that of urban households, and access to information is narrower. Families with social networks will help their rural families to broaden their access to funds and information. At the same time, compared with cities, there are fewer employment opportunities in rural areas, and rural families are more likely to choose business operations as their profession. Therefore, the positive impact of social networks on rural family entrepreneurship is greater than the positive impact of social networks on urban family entrepreneurship.

Table-8: Urban and Rural Heterogeneity of Social Network's Impact on Family Entrepreneurship

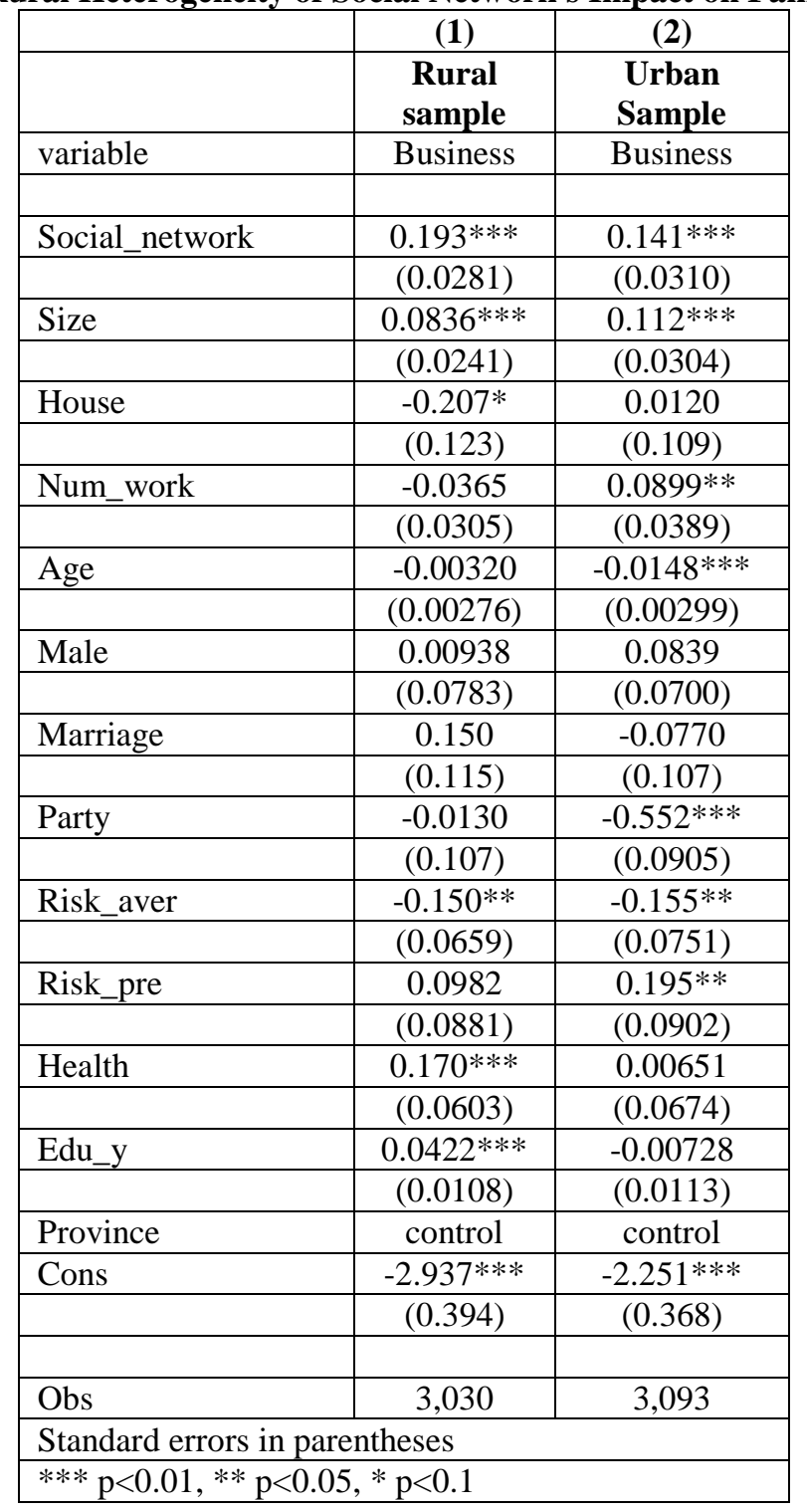

\section{CONCLUSION}

This article uses the data from the 2011, 2013 and 2015 China Household Finance Survey to empirically analyze the impact of social networks on household entrepreneurship and its mechanism. After correcting the endogenous problem, this article finds that social networks can help increase the probability of urban and rural families starting a business. The positive impact of social networks on rural families' entrepreneurship is greater than the positive impact of social networks on urban families. The main mechanism of social network influencing family entrepreneurship is to broaden family information 
channels and financing channels. Social networks can increase information acquisition, thereby reducing information asymmetry, reducing transaction costs, helping families accurately understand and grasp market dynamics, and have a positive impact on the possibility of family entrepreneurship. At the same time, social networks have significantly increased the possibility of family entrepreneurship by broadening financing channels and easing credit constraints.

\section{Therefore, this article proposes the following policy recommendations}

First play the role of social networks to encourage more families to participate in the "double entrepreneurship" tide; the government should establish corresponding policies to guide financial institutions to issue entrepreneurial loans, so that financial institutions lower the threshold for entrepreneurial loans and ease the process of family entrepreneurship The third is to encourage private finance to enter the financial service field and regulate the private financial market to better serve family entrepreneurship; the fourth is to improve the market-led economic system as soon as possible to reduce the information asymmetry in the transaction process. Reduce transaction costs and encourage more families to start entrepreneurship and innovation.

\section{REFERENCE}

1. Chai Shijun, Social Network and Household Entrepreneurship Decision. Empirical Evidence from Chinese Family Panel Studies, Journal of Yunnan University of Finance and Economics. 2017; 06: 111-122.

2. He Cuixiang, Yan Bing, Social networks, Financing Channels and Family Entrepreneurship - A Study based on the data of China's Household Finance Survey, South China Finance.2015; 11: 30-37.

3. Zhang Bo, Hu Jinyi, Fan Chenchen, Social Network, Information Acquisition and Households'Entrepreneurial Income: An Empirical Research Based on Perspective of Urban - rural Differences in China, Economic Review. 2015; 02: 52-67.

4. Hu Hao, Wang Haiyan, Social Interaction and rural Family Entrepreneurial Decision-Making, Entrepreneurial Motivation, Soft Science. 2019; 03: 26-29.

5. Chen Xiding, Zhang Fangfang, Huang Qinghua, Duan Lingling, The Influence of Infrastructure on
Rural Household's Entrepreneurship, Journal of Agrotechnical Economics.2018; 04: 80-89.

6. Lv Jing, Guo Pei, Cheng Jian, The Influence of Social Relation and Heterogeneity of Risk Preference on Family Entrepreneurship Activity, Journal of Financial Development Research.2018; 10: 22-28.

7. Yang Huaijia, Zhang Bo, Saving Ratio, Wealth and Household Entrepreneurship----Analysis Based on the CHFS Data, Journal of Shanxi University of Finance and Economics. 2019; 11: 14-26.

8. Fairlie RW. Entrepreneurship, economic conditions, and the great recession. Journal of Economics \& Management Strategy. 2013 Jun;22(2):207-31.

9. Chen Gang, The Regulation and the Entrepreneurship: The Micro Evidence from China, Management World, 05(2015),89-99+187-188.

10. Zhang Xiu-e, Meng Qiao, An Analysis of China's Entrepreneurial Institutional Environment — Based on the Comparison between China and Innovationdriven Economies, East China Economic Management, 2018; 06: 5-11.

11. Allen F and Gale D. Financial contagion. Journal of political economy, 2000; 108(1): 1-33.

12. Yin Zhichao, Song Quanyu, Wu Yu, Peng Changyan, Financial knowledge, entrepreneurial decision and entrepreneurial motivation, Management World. 2015; 01: 87-98.

13. Jingyi Y, Shiyu B, Cong L, Yexin Z. The Levels of Social Network and Wage of Rural-urban Migrants: From a Perspective of Indentity Model [J]. Economic Review. 2012;4.

14. Kinnan C, Townsend R. Kinship and financial networks, formal financial access, and risk reduction. American Economic Review. 2012 May;102(3):289-93.

15. Linda YU. Self-employment in urban China: Networking in a transition economy. China Economic Review. 2009 Sep 1;20(3):471-84.

16. Lu J, Wang Z, Cao J, Ho DW, Kurths J. Pinning impulsive stabilization of nonlinear dynamical networks with time-varying delay. International Journal of Bifurcation and Chaos. 2012 Jul;22(07):1250176.

17. Wen D, Ding Y. Experimental investigation into convective heat transfer of nanofluids at the entrance region under laminar flow conditions. International journal of heat and mass transfer. 2004 Nov 1;47(24):5181-8. 